\title{
Studies on Ergosterol liquid membrane using Amphotericin B
}

\section{Vandana Mishra*}

Department of Chemistry, Marwar Business School, Gorakhpur, India

\begin{abstract}
Amphotericin B is an antifungal polyene antibiotic obtained from a strain of Streptomyces nodosus. Some cancer tumors are composed of fungal tissue called ergosterol. Amphotericin B binds to ergosterol in the cell membrane of susceptible fungi with a resultant change in membrane permeability allowing leakage of intracellular components. To study the role of amphotericin B on ergosterol membrane, cellulose acetate matrix has been used as a support on which the liquid membrane of ergosterol has been formed. $\mathrm{NaCl}$ has been used as the electrolyte which is transported through the membrane. Membrane potential, perm selectivity and fixed charge density values have been used to examine the action of amphotericin B on ergosterol.
\end{abstract}

Keywords: Liquid membrane study with amphotericin B

\section{Introduction}

Ergosterol is a fungal product and a biologically important material. During study, it has been noticed that inspite of having great biological significance, ergosterol causes several fungal diseases in human body and some cancer tumors are composed of fungal tissue called ergosterol. For this reason we used amphotericin B which is a polyene antifungal agent. It is an amphoteric compound composed of a hydrophilic polyhydroxyl chain along one side and a lipophilic polyene hydrocarbon chain on the other (Figure 1). Amphotericin B binds to sterols [1] preferentially to the primary fungal cell membrane sterol, ergosterol. This binding disrupts osmotic integrity of the fungal membrane, resulting in leakage

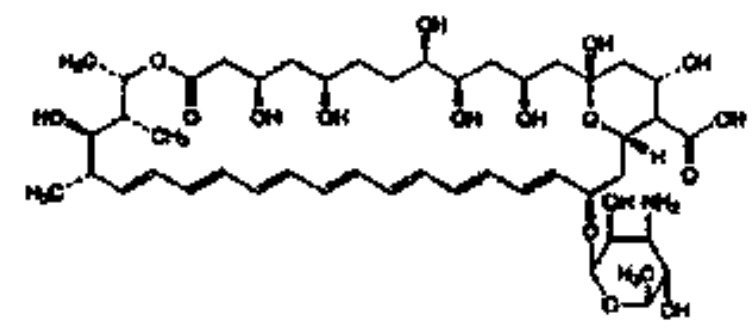

Figure 1: Amphotericin B.

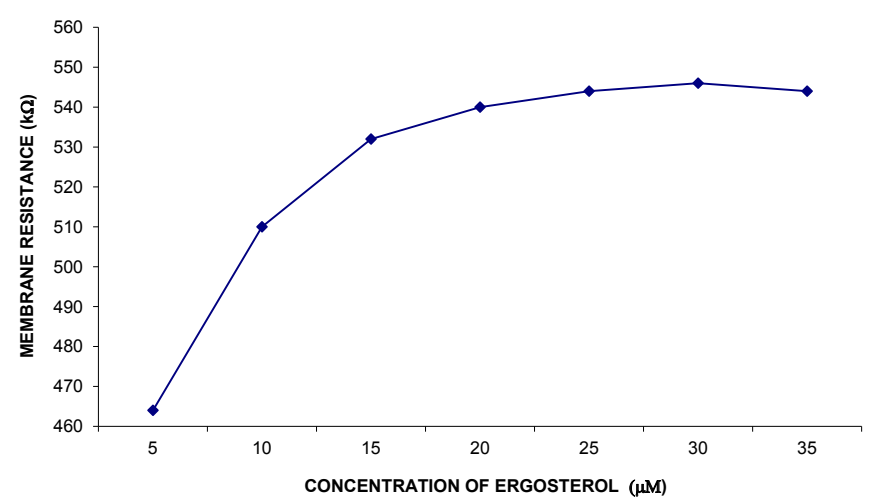

Figure 2: The maximum membrane resistance for a cellulose acetate supported ergosterol liquid membrane. of intracellular sodium, potassium, magnesium, sugars and metabolites and then cellular death [2]. Membrane potential has been measured using $\mathrm{NaCl}$ solutions of different mean concentrations to examine the action of amphotericin B on ergosterol liquid membrane.

\section{Materials and Methods}

Cellulose acetate film was prepared as already reported [3]. The liquid membrane was generated [4,5] by using the method of Pagano and Gershfeld [6]. Generation of liquid membrane was carried out by first equilibrating the film with water and then keeping it in contact with ergosterol solution of lowest concentration. Membrane resistance was measured. The critical micelle concentration (CMC) was found to be $20 \mu \mathrm{M}$. Ergosterol dispersions of higher concentration $(35 \mu \mathrm{M})$ were used in the present study.

Membrane potential was measured [7] with the help of digital multimeter (MAS 830) using calomel electrodes. Sodium chloride solutions of different concentrations with and without ergosterol were kept on either side of the supported matrix to allow equilibration and liquid membrane formation.

The solution of known concentration of amphotericin B (MEDISPEC Pharmaceuticals Pvt. Ltd.) was prepared by dissolving a known amount of amphotericin B in water. During membrane potential measurement, a known volume of amphotericin B was also used in the solutions of sodium chlorides of different concentrations.

\section{Results and Discussion}

The liquid membrane formation was ascertained by measuring membrane resistance using ergosterol suspensions of different concentrations. Due to accumulation of ergosterol in the interfacial region, the resistivity changed and approached a constant value after 3-4 $\mathrm{h}$ (Figure 2). Membrane potential was measured using the experimental cell of the type:

*Corresponding author: Vandana Mishra, Department of Chemistry, Marwar Business School, Gorakhpur, India, E-mail: vandana_gkp@yahoo.com, Vndnpdh03@gmail.com

Received August 26, 2013; Accepted September 30, 2013; Published October 03, 2013

Citation: Mishra V (2013) Studies on Ergosterol liquid membrane using Amphotericin B. J Membra Sci Technol 3: 123. doi:10.4172/2155-9589.1000123

Copyright: ( 2013 Mishra V. This is an open-access article distributed under the terms of the Creative Commons Attribution License, which permits unrestricted use, distribution, and reproduction in any medium, provided the original author and source are credited. 


\begin{tabular}{|c|c|c|c|c|}
\hline Mean Conc. & $\mathrm{C}_{1}$ & $\mathrm{C}_{2}$ & \multicolumn{2}{|c|}{$\mathrm{E}(\mathrm{mV})$} \\
\hline$\left(\mathrm{mol}^{\left.-\mathrm{dm}^{-3}\right)}\right.$ & $\left(\mathrm{mol}^{-} \mathrm{dm}^{-3}\right)$ & $\left(\mathrm{mol}^{\left.-\mathrm{dm}^{-3}\right)}\right.$ & $\begin{array}{c}\text { Without } \\
\text { ergosterol }\end{array}$ & $\begin{array}{c}\text { With } \\
\text { ergosterol }\end{array}$ \\
\hline 0.15 & 0.2 & 0.1 & 14.9 & 12.5 \\
\hline 0.30 & 0.4 & 0.2 & 13.6 & 11.1 \\
\hline 0.45 & 0.6 & 0.3 & 12.3 & 10.3 \\
\hline 0.60 & 0.8 & 0.4 & 11.6 & 9.7 \\
\hline 0.75 & 1.0 & 0.5 & 10.3 & 9.1 \\
\hline
\end{tabular}

Table 1: Membrane potential data at different mean concentration of $\mathrm{NaCl}$ with and without ergosterol.

\begin{tabular}{|c|c|c|c|c|}
\hline \multirow{2}{*}{$\begin{array}{c}\text { Mean Conc. } \\
\left(\mathrm{mol}_{-} \mathrm{dm}^{-3}\right)\end{array}$} & $\begin{array}{c}\mathrm{C}_{1} \\
\left(\mathrm{~mol}_{\mathrm{dm}} \mathrm{dm}^{-3}\right)\end{array}$ & $\begin{array}{c}\mathrm{C}_{2} \\
\left(\mathrm{~mol}^{-3} \mathrm{dm}^{-3}\right)\end{array}$ & $\begin{array}{c}|c| \\
\text { Without } \\
\text { amphotericin B }\end{array}$ & $\begin{array}{c}\text { With amphotericin } \\
\text { B }\end{array}$ \\
\hline 0.15 & 0.2 & 0.1 & 12.5 & 15.0 \\
\hline 0.30 & 0.4 & 0.2 & 11.1 & 13.3 \\
\hline 0.45 & 0.6 & 0.3 & 10.3 & 12.3 \\
\hline 0.60 & 0.8 & 0.4 & 9.7 & 11.5 \\
\hline 0.75 & 1.0 & 0.5 & 9.1 & 10.3 \\
\hline
\end{tabular}

Table 2: Membrane potential data for cellulose acetate / ergosterol sodium chloride system with and without use of amphotericin B.

\begin{tabular}{|c|c|c|c|c|}
\hline \multirow{2}{*}{$\begin{array}{c}\text { Mean Conc. } \\
\left(\text { mol-dm }^{-3}\right)\end{array}$} & \multicolumn{2}{|c|}{ Ps } & \multicolumn{2}{c|}{$\phi \bar{X}\left(\mathrm{~mol}_{\left.-\mathrm{dm}^{-3}\right)}\right.$} \\
\cline { 2 - 5 } & $\begin{array}{c}\text { Without } \\
\text { amphotericin B }\end{array}$ & $\begin{array}{c}\text { With amphotericin } \\
\text { B }\end{array}$ & $\begin{array}{c}\text { Without } \\
\text { amphotericin B }\end{array}$ & $\begin{array}{c}\text { With } \\
\text { amphotericin } \\
\text { B }\end{array}$ \\
\hline 0.15 & 0.8869 & 0.9975 & 0.5762 & 4.2320 \\
\hline 0.30 & 0.8766 & 0.9715 & 1.2411 & 2.4595 \\
\hline 0.45 & 0.8664 & 0.9675 & 1.5032 & 3.4433 \\
\hline 0.60 & 0.8645 & 0.9589 & 2.0639 & 4.0529 \\
\hline 0.75 & 0.8611 & 0.9276 & 2.5405 & 3.7245 \\
\hline
\end{tabular}

Table 3: Permselectivity and fixed charge density values for cellulose acetate ergosterol - sodium chloride system with and without use of amphotericin B.

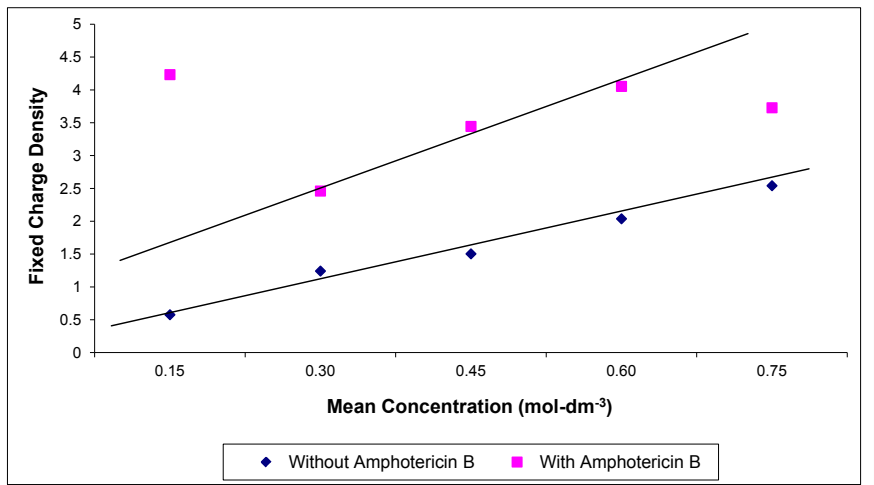

Figure 3: Variation of fixed charge density with mean concentration for cellulose acetate/ergosterol- $\mathrm{NaCl}$ system.

\begin{tabular}{|c|c|c|c|c|}
\hline $\begin{array}{c}\text { Reference Calomel } \\
\text { Electrode }\end{array}$ & Solution & Membrane & Solution & $\begin{array}{c}\text { Reference Calomel } \\
\text { Electrode }\end{array}$ \\
\hline
\end{tabular}

Liquid membrane formation was indicated by the lowering of membrane potential which can be seen in Table 1 .

Cellulose acetate is practically uncharged and its selectivity is very low. Perm selectivity was calculated by the equation [8].

$$
\mathrm{P}_{\mathrm{S}}=\frac{\overline{\mathrm{t}_{+}}-\mathrm{t}_{+}}{\mathrm{t}_{+}-\left(2 \mathrm{t}_{+}-1\right) \overline{\mathrm{t}_{+}}}
$$

The transport number on the basis of TMS theory for 1:1 electrolyte i.e. for $\mathrm{NaCl}$ may be given as [9],

$$
\bar{t}_{+}=\frac{E}{2 E_{\max }}+0.5
$$

Where, the symbols have their usual meaning. A simplification of TMS theory gives:

$$
E=\frac{R T}{F}\left(2 \bar{t}_{+}-1\right) \ln \frac{\mathrm{a} 1}{\mathrm{a} 2}
$$

and if the membrane is ideally selective,

$$
\mathrm{E}_{\max }=\frac{\mathrm{RT}}{\mathrm{F}} \ln \frac{\mathrm{a}_{1}}{\mathrm{a}_{2}}
$$

Perm selectivity is related to fixed charge density as [10]

$$
\varphi \bar{x}=\frac{\overline{2 c} P_{s}}{\sqrt{1-P_{s}^{2}}}
$$

Where $\overline{\mathrm{c}}$ is the mean concentration?

Table 1 includes the values of membrane potential for cellulose acetate - sodium chloride system with and without ergosterol. From the table, it is found that the membrane potential values decrease with increasing mean concentration and the values without ergosterol are greater in comparison to those with ergosterol.

Table 2 includes the values of membrane potential for cellulose acetate/ ergosterol-sodium chloride system with and without use of amphotericin B. If we compare Tables 1 and 2, we find that membrane potential values for cellulose acetate/ergosterol - sodium chloride system with amphotericin B are approximately the same as those for cellulose acetate - sodium chloride system without ergosterol. It shows that use of amphotericin B in the system is responsible to remove the effect of ergosterol as a surfactant in the membrane. It may be due to the fact that amphotericin B binds to ergosterol and disrupts its osmotic integrity.

Table 3 contains the values of perm selectivity and fixed charge density for cellulose acetate/ergosterol - sodium chloride system with and without use of amphotericin B. It is found that in the presence of Amphotericin B, the perm selectivity values tend to become nearly equal to one (i.e., $0.9975 \simeq 1$ ). Fixed charge density values also variate in a random way as is clear from the (Figure 3). This indicates that in the presence of amphotericin $\mathrm{B}$, there in a diminishing trend in the surfactant behavior of Ergosterol in the membrane.

\section{Acknowledgement}

The authors are thankful to the Head, Department of Chemistry, D.D.U. Gorakhpur University, Gorakhpur, for providing laboratory facilities.

\section{References}

1. Terrell CL, Hughes CE (1992) Antifungal agents used for deep-seated mycotic infections. Mayo Clin Proc 67: 69-91.

2. Burger A (2003) Medicinal Chemistry. Wiley interscience, New Jersey, USA 5 889-893.

3. Singh K, Tiwari AK (1987) Membrane potential studies on cholesterol liquid membranes. J Membrane Sci 34: 155-163.

4. Srivastava RC, Jakhar RPS (1981) Transport through liquid membranes generated by cholesterol. J Phys Chem 85: 1457-1460.

5. Upadhyay V (1987) Studies of Cellulose Acetate Supported Ergosterol Liquid Membrane. J Colloid Interface Sci 2: 116. 
6. Pagano RE, Gershfeld NL (1972) Physical chemistry of lipid films at the airwater interface. II. Binary lipid mixtures. Principles governing miscibility of lipids in surfaces. J Phys Chem 76: 1238-1243.

7. http://www.niscair.res.in/sciencecommunication/researchjournals/rejour/ijcb/ ijcb0.asp
8. http://www.journals.elsevier.com/progress-in-polymer-science/

9. Läuger P (1969) Transport Phenomena in Membranes. Angewandte Chemie 8: $42-54$.

10. http://www.niscair.res.in/sciencecommunication/researchjournals/rejour/ijca/ ijca0.asp 